\title{
ПСИХОЛОГІЧНІ ОСОБЛИВОСТІ ФУНКЦІОНУВАННЯ ФЕНОМЕНУ ПРОКРАСТИНАЦІЇ У СТУДЕНТСЬКОЇ МОЛОДІ
}

У статті здійснено аналіз особливостей функціонування прокрастинації в студентському віці. Висвітлено та узагальнено вітчизняні та зарубіжні дослідження феномена. Виділені особливості прояву прокрастинації у сучасному молодіжному середовищі. Розглянуто основні типи прокрастинації. Визначені змістові аспекти розуміння прокрастинації як комплексного та 
неоднорідного, з психологічної точки зору, феномена. Експериментально проаналізовано зв'язок прокрастинації з особливостями копінг-стратегій та феноменом відповідальності.

Ключові слова: прокрастиначія, копінг-стратегії, бездіяльність, відповідальність, воля.

В статье осуществлен анализ особенностей функционирования прокрастинации в студенческом возрасте. Освещены и обобщены отечественные и зарубежные исследования феномена. Проанализированы особенности проявления прокрастинации в современной студенческой среде. Рассмотрены основные типь прокрастинации. Определены содержательные аспекты понимания прокрастинации как комплексного и неоднородного, с психологической точки зрения, феномена. Проанализирована связь прокрастинации с особенностями копинг-стратегий а также феноменом ответственности.

Ключевые слова: прокрастинация, копинг-стратегии, бездействие, ответственность, воля.

Постановка проблеми. Сучасне суспільство вимагає від людини володіння стійкими позитивними психологічними якостями, зокрема цілеспрямованістю, наполегливістю, впевненістю, організованістю, конкурентоспроможністю, прогнозованістю тощо. Все це, у поєднанні 3 життєстійкістю та оптимізмом, є запорукою формування успішної особистості [1]. Проте останнім часом все більше увагу науковців привертає явище прокрастинації, яке виявляється у затримці або відкладенні на останній момент виконання важливої діяльності чи прийняття рішень. Подібна стратегія хоч і належить до явищ, які прямо не загрожують життю людини, але можуть значно

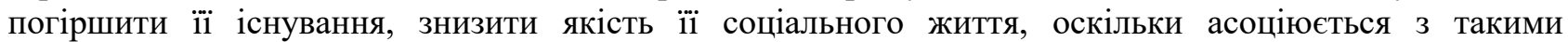
негативними характеристиками як «бути поганим», «завдавати шкоди», «відчувати себе безвідповідальним». Більше того, за даними зарубіжних досліджень, біля 95 відсотків респондентів, що визнають у себе наявність цієї стратегії, бажають якщо не позбутися іiі, то, принаймні, значно знизити ії рівень [10].

Аналіз останніх досліджень та публікацій. Вивчення феномена прокрастинації розпочалося ще у 70-х роках XX століття. Появу терміна «прокрастинація» (від лат. procrastinare) для позначення схильності людини відкладати на потім, на майбутнє неприємні рішення та справи, пов'язують із роботою П. Рінгенбах (P. Ringenbach) «Прокрастинація в житті людини». Проте, як показали останні дослідження, ця книга ніколи не була завершеною та опублікованою, більше того вона була задумана автором як науковий жарт. Першим реальним науковим аналізом феномена вважають роботу H. Мілграма (N. Milgram) «Прокрастинація: хвороба сучасності» 3 вивчення взаємозв'язку рівня розвитку суспільства та прокрастинації, як відповіді особистості на соціальний тиск. Проте поглиблене вивчення феномена розпочалося лише з середини $80-$ х років.

Сьогодні прокрастинація розуміється як комплексне, неоднорідне у психологічному плані особистісне утворення, що включає в себе поведінкові, емоційні та когнітивні компоненти, які тісно пов'язані з мотиваційною сферою особистості. Основними лініями аналізу прокрастинації в останні десятиліття стало вивчення впливу прокрастинації на особистість $[1 ; 2]$ та ії̈ взаємозв'язку з різними особистісними феноменами [4; 7], зіставлення позитивних та негативних наслідків прокрастинації для особистості [9]; аналіз впливу прокрастинації на ефективність діяльності та прийняття рішень у різних сферах, зокрема економічній та політичній [10]; розробка психодіагностичного інструментарію з вивчення феномена загалом та його окремих аспектів [8].

У пострадянському науковому просторі явище прокрастинації є малодослідженим. Існує лише невелика кількість робіт у цьому напрямку[1; 2; 3]. В основному увага дослідників зосереджена на вивченні диспозиційних корелятів прокрастинації та іiі впливу на академічну успішність. (Я. Варварічева [2], О. Грабчак; А. Шиліна [5]).

Формулювання цілей статті. Зважаючи на те, що опанування майбутньою професією, формування відповідних умінь та навичок у процесі навчання в ЗВО та пов'язана 3 цим академічна успішність $\epsilon$ важливими елементами життя особистості в період ранньої дорослості, та спираючись на результати зарубіжних досліджень, які вказують на особливу широку розповсюдженість прокрастинації в студентському середовищі, ми маємо на меті проаналізувати психологічні особливості функціонування прокрастинації в період ранньої дорослості.

Виклад основного матеріалу дослідження. У зв'язку 3 сучасними трансформаційними процесами у освіті, що передбачають зміну мети, способів, результатів діяльності студентів, все більшу роль набуває самоосвіта, виконання практичних завдань, участь у наукових дослідженнях, професійно орієнтованих програмах. Все це вимагає від студента сконцентрованості, відповідального ставлення до навчання, високого рівня саморегуляції. Проте саме недостатній розвиток емоційно вольової та мотиваційної сфер є однією з головних причин прокрастинації. 
Студенти з нерозвиненими, несформованими вольовими процесами нездатні перебороти власні лінощі відмовитися від більш привабливих видів діяльності та зосередитись на виконанні завдань, що не може не відобразитися на рівні академічної успішності. Це, у свою чергу, зумовлює переживання молодою людиною стану емоційної напруги, почуття провини та власної неефективності.

Все ж варто зазначити, що більшість дослідників наголошують на тому, що не можна будьяке відкладання вирішення справи трактувати як прокрастинацію, оскільки не всі затримки призводять до негативних наслідків [10]. Значна кількість молодих людей, розпочинаючи працювати в останню хвилину, можуть закінчити завдання вчасно, і їх діяльність характеризується вищою швидкістю та продуктивністю. Тому доцільним $є$ виокремлення декількох типів прокрастинації: тимчасової, коли студент витрачає час на інші, приємніші заняття й розваги, та хронічної, яка пов'язана із загальним перевантаженням, втратою відчуття часу, незадоволеністю власними досягненнями, неясними життєвими цілями, нерішучістю і невпевненістю в собі [2].

Перший тип прокрастинації, який найбільш часто зустрічається серед студентів, не має значного негативного впливу на особистість молодої людини. Він є своєрідною формою негативної реакції на заплановані чи необхідні справи та певним способом уникання неприємних, негативних переживань, почуттів, які пов'язані з виконанням того, що людина відкладає. У той час як хронічна прокрастинація заважає праці, навчанню, успіху, реалізації майбутніх планів та має значний негативний влив на ставлення особистості до себе та оточуючих. Крім того вона може бути прихованим початком психологічного чи фізичного захворювання.

За результатами попередніх досліджень, саме хронічна прокрастинація притаманна тим студентам, що неправильно обрали фах та навчальний заклад [6].

Для вивчення психологічних особливостей феномену прокрастинації та його зв'язку з копінг - стратегіями особистості та відповідальністю, нами було проведене експериментальне дослідження, в якому взяли участь 30 студентів психологічного факультету РДГУ, віком 21-22 роки. В якості діагностичного інструментарію нами було обрано

1. Опитувальник загальної прокрастинації (шкала GP) К. Лея (адаптація Юдєєва Т.Ю., Гаранян Н.Г., Жукова Д.Н.), який призначений для визначення рівня прокрастинації в повсякденному житті. Опитувальник складається з 20 тверджень, (10 прямих і 10 «зворотних»), що описують уникання виконання завдань, або відкладання їх на потім.

2. «Мельбурнський опитувальник прийняття рішень» МОПР / MDМА - особистісний опитувальник, призначений для діагностики індивідуального стилю прийняття рішень в умовах невизначеності, стилю подолання стресу (копінг-стратегіï). Методика розроблена в 1997 році Л. Манном та його колегами (L. Mann, P. Burnett, M. Radford, S. Ford) на основі більш раннього опитувальника того ж автора (Flinders Decision Making Questionnaire, 1982) та адаптована Т. В. Корніловою. Оцінювання та інтерпретація результатів проводиться за шкалами: пильність, уникання, прокрастинація, надпильність.

3. Методика «Багатовимірно-функціональна діагностика відповідальності (ОТВ-70)». Ідея багатовимірно-функціонального аналізу окремих властивостей і якостей особистості належить А. І. Крупнову, ним же був розроблений початковий варіант опитувальника - 210 питань. Відповідальність, як якість, розглядається з позиції єдності операціональної (природно-заданої) i змістовної (прижиттєво-надбаної) сфери. У операціональний блок увійшли наступні компоненти: динамічний (розкривається за допомогою полярних параметрів: ергічність-аергічність); емоційний (стенічність-стомлюваність); регуляторний (інтернальність-екстернальність).

У змістовний блок увійшли такі компоненти: мотиваційний (соціоцентричністьегоцентричність); когнітивний (осмисленість-обізнаність); результативний (предметністьсуб'єктність).

Аналіз результатів дослідження Отримані результати вказують на переважання середніх показників прокрастинації у студентів (див. рис. 1). Молодь схильна відкладати справи або вирішення завдань на потім тільки тоді, коли ця проблема не має суттєвого значення для них, тому і наслідки даної прокрастинації не будуть вносити суттєві зміни у роботу. Тобто, усвідомлюючи необхідність виконання цілком конкретних важливих справ, студенти ігнорують цю необхідність і переорієнтовують свою увагу на побутові дрібниці або розваги. 


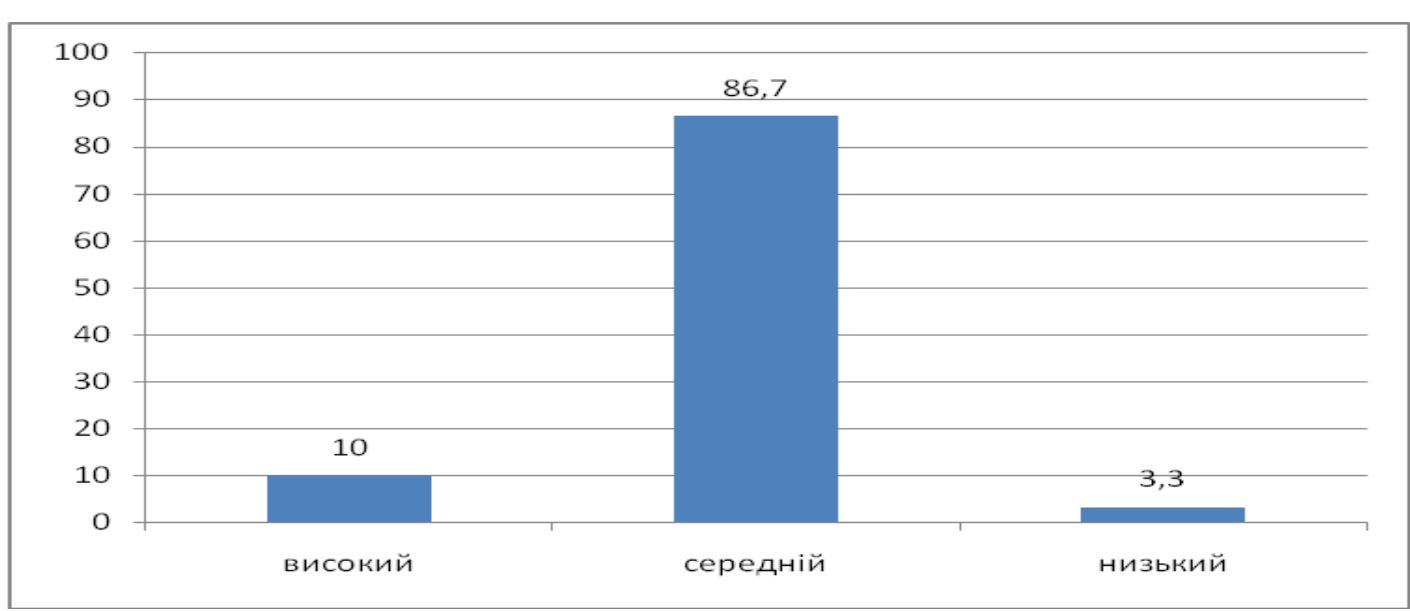

\section{Рис.1. Кількісні показники підгруп студентів із різним рівнем прокрастинації (у\%)}

Значно менше студентів продемонстрували високий рівень прокрастинації, показник обсягу цієї групи становить - 10 \%. Такі студенти зазвичай, працюють хаотично, без плану, лише за наявності натхнення чи фактору невідкладності. Вони в значно меншій мірі концентруються на майбутніх негативних наслідках свого ухилення від запланованих справ через прагнення до миттєвих винагород. Прострочивши терміни вирішення завдання, просто відмовляються від запланованого, або намагаються зробити все відкладене за якомога короткий проміжок часу. У результаті, завдання не виконуються або виконуються неякісно, із запізненням і не в повному обсязі, що призводить до негативних наслідків у вигляді зниження академічної успішності, тривоги, стресу, втрати продуктивності, переживання почуття провини за невчасно виконане завдання. Незначна представленість респондентів з низьким рівнем прокрастинації $(3,3 \%)$, на нашу думку, може зумовлюватися як віковими, так і диспозиційними змінними, і свідчити про те, що елементи уникання вирішення завдань притаманні практично усім.

У той же час, згідно результатів «Мельбурнського опитувальника прийняття рішень», низькі показники за шкалою прокрастинації були зафіксовані у 40\% студентів (див табл.1). Як видно 3 таблиці, показники високого рівня прокрастинації співпали за обома методиками. Зафіксована розбіжність пояснюється, на нашу думку, дещо різною спрямованістю діагностичного інструментарію. Мельбурнський опитувальник звужує поле потенційної прокрастинації лише до особливостей прийняття рішень, що зумовлює відмінності у розумінні та інтерпретації питань студентами.

Таблиия 1

Показники особливостей копінг-стратегій студентів за результатами «Мельбурнського опитувальника прийняття рішень» (у \%)

\begin{tabular}{|c|c|c|c|c|}
\hline \multirow{2}{*}{ Показники } & \multicolumn{4}{|c|}{ Типи копінг-стратегій } \\
\cline { 2 - 5 } & пильність & уникнення & прокрастинація & надпильність \\
\hline \multirow{2}{*}{ високі } & 40 & - & 10 & 10 \\
\hline середні & 50 & 43 & 50 & 62 \\
\hline низькі & 10 & 67 & 40 & 28 \\
\hline
\end{tabular}

Для виявлення взаємозв'язків між усіма показниками означених психічних явищ (прокрастинації, параметрів відповідальності та копінг-стратегій у прийнятті рішень), діагностичний комплекс був доповнений процедурою статистичної обробки результатів із використанням методу рангової кореляції Спірмена.

Отримані результати свідчать про наявність позитивного кореляційного зв'язку між стратегією уникання у процесі прийняття важливих рішень та прокрастинацією $\left(\mathrm{r}_{\mathrm{s}}=0.474(\mathrm{p} \leq 0.05)\right.$. Це може пояснюватися наявністю спільної диспозиційної детермінуючої платформи (рівень самооцінки, локус контролю, рівень домагань, тощо). Проте варто зазначити, що ці феномени не $\epsilon$ тотожними. Уникання передбачає відмову від прийняття рішення, неприйняття відповідальності, перекладання іiі на інших людей, що може мати значний негативний вплив на розвиток особистості, в той час як прокрастинація не завжди передбачає повну відмови від діяльності в ситуації необхідності. 
Позитивний зв'язок встановлено також між шкалами прокрастинації обох опитувальників $\left(\mathrm{r}_{\mathrm{s}}\right.$ $=0.629$ (p $\leq 0.05)$. Зворотній кореляційний зв'язок прослідковується між шкалою пильності та прокрастинації $\left(\mathrm{r}_{\mathrm{s}}=-0.425(\mathrm{p} \leq 0.05)\right.$. При цьому зв'язок між показником надпильності та прокрастинації не є статистично значущим $\left(\mathrm{r}_{\mathrm{s}}=0.218(\mathrm{p}>0.05)\right.$.

Таблиия 2

Показники взаємозв'язку прокрастинації з особливостями прийняття рішень

\begin{tabular}{|c|c|}
\hline Тип копінг-стратегії & \multicolumn{1}{|c|}{ Значення } \\
\hline пильність & $-0.425^{*}$ \\
\hline прокрастинація & $0.629^{*}$ \\
\hline уникання & $0.474^{*}$ \\
\hline надпильність & 0.218 \\
\hline
\end{tabular}

"p $\leq \mathbf{0 . 0 5}$ отриманих показників кореляційного аналізу прокрастинації та параметрів відповідальності (див.табл. 3), дозволяє стверджувати про наявність помірних зв'язків показників: динамічної ергічності та прокрастинації $\left(\mathrm{r}_{\mathrm{s}}=-0.423(\mathrm{p} \leq 0.05)\right.$, регуляторної інтернальності та прокрастинації $\left(\mathrm{r}_{\mathrm{s}}=-0.433\right.$ ( $\left.\mathrm{p} \leq 0.05\right)$, когнітивної обізнаності та прокрастинації $\left(\mathrm{r}_{\mathrm{s}}=0.433(\mathrm{p} \leq 0.05)\right.$, предметної результативності та прокрастинації $\left(\mathrm{r}_{\mathrm{s}}=-0.391 \quad \mathrm{p} \leq 0.05\right)$. Тобто здатність бути самостійним у вирішенні завдань, без наявності додаткового контролю, детальне виконання важких і відповідальних завдань; незалежність при виконанні поставлених завдань, продуктивність, сумлінність $є$ тими складниками відповідальності, які будуть перешкоджати людині відкладати важливі справи на останній момент, або відмовлятися від їх виконання. Нами був виявлений лише один статистично значущий параметр, позитивно пов'язаний з прокрастинацією. Це так звана когнітивна обізнаність, яка передбачає недостатнє усвідомлення людиною відповідальності, звертання уваги лише на окремі iї аспекти.

Таблиия 3

Показники кореляційного зв'язку параметрів відповідальності та прокрастинації

\begin{tabular}{|l|l|}
\hline Показники & \multicolumn{1}{|c|}{ Значення } \\
\hline динамічна ергічність & $\mathbf{- 0 . 4 2 3 *}$ \\
\hline динамічна аергічність & 0.277 \\
\hline емоційність стенічна & -0.344 \\
\hline емоційність астенічна & -0.279 \\
\hline регуляторна інтернальність & $\mathbf{- 0 . 4 3 3}$ \\
\hline регуляторна екстернальність & 0.113 \\
\hline мотивація соціоцентрична & -0.214 \\
\hline мотивація егоцентрична & 0.26 \\
\hline когнітивна осмисленість & -0.137 \\
\hline когнітивна обізнаність & $\mathbf{0 . 4 3 3}$ \\
\hline результативність предметна & $\mathbf{- 0 . 3 9 1 *}$ \\
\hline результативність суб'єктна & -0.123 \\
\hline
\end{tabular}

*p $\leq 0.05$

Слабкий кореляційний зв'язок, виявлений між динамічною аергічністю та прокрастинацією, на нашу думку, може пояснюватися особливостями формулювання питань та відповідно інтерпретацією їх респондентами. Загалом, отримані результати дозволяють робити висновок про досить складний та неоднозначний зв'язок між феноменами прокрастинації та відповідальності, що потребує подальшого вивчення.

Висновки та перспективи подальших досліджень. Проведене теоретичне та експериментальне дослідження дозволяє стверджувати, що прокрастинація $є$ комплексним, неоднорідним, у психологічному плані, феноменом, що включає в себе поведінкові, емоційні та когнітивні компоненти, які тісно пов'язані з мотиваційною сферою особистості. Він проявляється, перш за все, у поведінці, у затримці виконання необхідної діяльності, а також у відкладанні прийняття рішень та відповідальності.

Студенти $є$ певною «групою ризику» для розвитку прокрастинації, що зумовлено як соціальними (високий рівень самостійності, практично відсутній зовнішній контроль), так і особистісними причинами (недостатній розвиток емоційно-вольової та мотиваційної сфери ). Часто це $\epsilon$ своєрідною формою втечі від умов реального світу. Нами було встановлено, що всі респонденти мають досвід прокрастинації, а близько 10 відсотків молодих людей перетворюють цю деструктивну форму поведінки особистості відносно організації власного просторово-часового континиуму на

Випуск 11, 2018. Збірник наукових праць РДГУ 
спосіб життя, що значно ускладнює взаємодію з соціальним оточенням та може спричиняти низку особистісних проблем та розладів. Результати проведеного дослідження виявили наявність зв'язку прокрастинації 3 особливостями копінг-стратегій особистості та проілюстрували досить неоднозначний зв'язок прокрастинації з феноменом відповідальності.

Перспективним напрямком дослідження є здійснення подальшого аналізу диспозиційних корелятів прокрастинації, психологічних особливостей прояву феномена на різних вікових етапах, 3 метою розробки ефективних засобів профілактики та корекції цієї особистісної стратегії.

\section{Список використаних джерел}

1. Быкова Д. В. Прокрастинация как проявление эмоционально-ориентированного и ориентированного на избегание стилів копинга / Д. В. Быкова // Психология совладающего поведения : материалы II Междунар. науч.-практ. конф., (Кострома, 23-25 сент. 2010 г.) / отв. ред. : Т. Л. Крюкова, М. В. Сапоровская, С. А. Хазова. - 2-е изд. - Кострома : КГУ им. Н. А. Некрасова, 2010. T. 1. - C. 194-196.

2. Варваричева Я. И. Феномен прокрастинации: проблемы и перспективы исследования / Я. И. Варваричева // Вопросы психологии. - 2010. - № 3. - С. 121-131.

3. Корнилова Т. В. Психология риска и принятия решений / Т. В. Корнилова. - М. : Аспект Пресc, 2003. -242 c.

4. Малкина-Пых И. Г. Стратегии поведения при стрессе / И. Г. Малкина-Пых // Московский психологический журнал. - 2007. - № 12. - С. 15-25.

5. Шиліна А. А. Особливості самовідношення студентів з різним рівнем прокрастинації / А. А. Шиліна, К. В. Свсігнєєва // Вісник Харківського національного університету імені В. Н. Каразіна. Серія : Психологія. - 2011. - № 985, вип. 48. - С. 41-45.

6. Baumeiseter R. F. Willpower : Rediscovening the greatest Human strength / R. F. Baumeiseter, J. Tierney. - Penguin Press, 2011. - 304 p.

7. Chu A. H. Rethinking procrastination: Positive effects of «active» procrastionation behavior on attitudes and performance / A. H. Chu, J. N. Choi // Journal of Social Psychology.- 2005. - № 145 (3). P. 245-264.

8. Ferrari J. R. Procrastination and task avoidance: theory research and treatment / J. R. Ferrari, J. I. Jonhson, W. G. MacCown. - NewYork : Plenum Press, 1995. - 268 p.

9. Pychyl T. A. Time traveling to Reduce Procrastination (and «Tough Love» for Procrastinations) Being more realistic about the future to descrease procrastination [Electronic resource] / T. A. Pychyl // Don't delay. - 2009. - Access mode : http://www.psychologytoday.com/blog/don't-delay.

10. Steel P. The nature of procrastination: A metaanalytic and theoretirical review of self regulatory failure / P. Steel // Amer. Psychol. Assoc. Bull. - 2007. - V. 133, № 1. - P. 66.

\section{References}

1. Byikova D. V. Prokrastinatsiya kak proyavlenie emotsionalno-orientirovannogo i orientirovannogo na izbeganie stillv kopinga / D. V. Byikova // Psihologiya sovladayuschego povedeniya : materialyi II Mezhdunar. nauch.-prakt. konf., (Kostroma, 23-25 sent. 2010 g.) / otv. red. : T. L. Kryukova, M. V. Saporovskaya, S. A. Hazova. - 2-e izd. - Kostroma : KGU im. N. A. Nekrasova, 2010. - T. 1. - S. 194-196.

2. Varvaricheva Ya. I. Fenomen prokrastinatsii: problemyi i perspektivyi issledovaniya / Ya. I. Varvaricheva // Voprosyi psihologii. - 2010. - № 3. - S. 121-131. 2003. $-242 \mathrm{~s}$.

3. Kornilova T. V. Psihologiya riska i prinyatiya resheniy / T. V. Kornilova - M. : Aspekt Press,

4. Malkina-Pyih I. G. Strategii povedeniya pri stresse / I. G. Malkina-Pyih // Moskovskiy psihologicheskiy zhurnal. -2007. - № 12. - S. 15-25.

5. Shylina A. A.Osoblyvosti samovidnoshennia studentiv z riznym rivnem prokrastynatsii / A. A. Shylina, K. V. Yevsihnieieva // Visnyk Kharkivskoho natsionalnoho universytetu imeni V. N. Karazina. Seriia : Psykholohiia. - 2011. -№ 985, vyp. 48. - S. 41-45.

6. Baumeiseter R. F. Willpower : Rediscovening the greatest Human strength / R. F. Baumeiseter, J. Tierney. - Penguin Press, 2011. - 304 p.

7. Chu A. H. Rethinking procrastination: Positive effects of «active» procrastionation behavior on attitudes and performance / A. H. Chu, J. N. Choi // Journal of Social Psychology. - 2005. - № 145 (3) - P. $245-264$. 
8. Ferrari J. R. Procrastination and task avoidance: theory research and treatment / J. R. Ferrari, J. I. Jonhson, W. G. MacCown. - NewYork : Plenum Press, 1995. - 268 p.

9. Pychyl T. A. Time traveling to Reduce Procrastination (and «Tough Love» for Procrastinations) Being more realistic about the future to descrease procrastination [Elektronnyy resurs] / T. A. Pychyl // Don't delay. - 2009. - Rezhym dostupu : http://www.psychologytoday.com/blog/don't-delay.

10. Steel P. The nature of procrastination: A metaanalytic and theoretirical review of self regulatory failure / P. Steel // Amer. Psychol. Assoc. Bull. - 2007. -V. 133, № 1. - P. 66.

\section{N. Korchakova, A. Kovbasa. STUDENTS' PROCTASTINATION: PSYCHOLOGICAL FEATURES OF FUNCTIONING.}

Procrastination is a complex phenomenon manifested in irrational delaying the important activities. Procrastination usually involves ignoring an unpleasant, but likely more important task, in favor of one that is more enjoyable or easier. According to the previous research most of the people have experience of procrastinating, but some of them have made it a way of life style, which causes the variety of personal and interpersonal problems (such as low self-esteem and self-efficiency, social anxiety, feeling guilty or ashamed). College students can be considered as a risk group for developing this destructive strategy. Researchers report that more than $80 \%$ percent of students admit engaging in it and wish to reduce such kind of behavior.

For local area of psychology procrastination is still a little-studied phenomenon. The first aim of our study is to examine the features of correlation between the level of procrastination and copping behavior; the next one - between procrastination and responsibility as the interpersonal trait. 30 20-21years-old students participated in our study. We found that only $3 \%$ of them had a low level of procrastination. It is corresponded with previous research. The majority of students had an occasional experience of postponing, delaying or putting off the activity or decision, which didn't cause any serious intrapersonal problems. But $10 \%$ of young people were found as high-level-procrastinators. Our results suggested that there was moderate connection between procrastination and the type of copping behavior. We also found complicated relationships between procrastination and separate components of responsibility, but the indirect nature of them requires the further study.

Key words: procrastination, copping behavior, will, inaction. 